\title{
Гидрогеохимическая характеристика подземных вод неогеновых отложений Палео-Волги в пределах территории г. Казань
}

\author{
С2021 Д. И. Петрова ${ }^{\bowtie}$, Р. Х. Сунгатуллин \\ Казанский (Приволжсский) федеральный университет, \\ Кремлевская 18,420008, Казань, Российская Федерация
}

\begin{abstract}
Аннотация
Введение: Одним из источников питьевого и промышленного водоснабжения г. Казань считается водоносный неогеновый терригенный комплекс. Целью исследования является гидрогеохимическая характеристика подземных вод неогенового комплекса для обеспечения г. Казани качественной питьевой водой из защищенных подземных источников.

Методика: Использованы гидрохимические данные из геологических отчетов и архивные материалы за период с 1971 по 2017 гг. Методы математической статистики (базовые, кластерный и факторный анализы) позволили провести дифференциацию на природные и техногенные компоненты. Геоинформационное моделирование с применением пакета «ArcGisMap» показало пространственную изменчивость основных компонентов в водах неогенового комплекса на рубеже XX и XXI столетий.

Результаты и обсуждение: В исследуемом водоносном комплексе выделены 2 группы компонентов: «природный» и «техногенный». К природным компонентам отнесены гидрокарбонаты, магний, кальций, минерализация, общая жесткость. Техногенными компонентами являются хлориды, общее железо, натрий и калий. В XXI веке выросла техногенная нагрузка на подземные водозаборные скважины централизованного водоснабжения из неогенового комплекса, что связано с их большим (40-50 лет) эксплуатационным сроком.

Заключение: Гидрохимические показатели водоносного неогенового терригенного комплекса оцениваются как благоприятные, так как практически все основные компоненты не превышают значений ПДК для питьевых вод. Высокое качество подземных вод палеодолины Волги позволяет считать их самым перспективным объектом водоснабжения Казани из подземных источников.

Ключевые слова: подземные воды, палеодолина, неогеновый комплекс, гидрохимия, статистика, ГИС, техногенез, мониторинг, Волга, Казань.

Источник финансирования: Работа выполнена за счет средств субсидии, выделенной в рамках государственной поддержки Казанского (Приволжского) федерального университета в целях повышения его конкурентоспособности среди ведущих мировых научно-образовательных центров.

Для ичитирования: Петрова Д. И., Сунгатуллин Р. Х. Гидрогеохимическая характеристика подземных вод неогеновых отложений Палео-Волги в пределах территории г. Казань // Вестник Воронежского государственного университета. Серия: Геология. 2021. №1. С. 114-123. DOI: https://doi.org/10.17308/geology.2021.1/3343
\end{abstract}

Контент доступен под лицензией Creative Commons Attribution 4.0 License.

\footnotetext{
${ }^{\square}$ Петрова Дарья Ивановна, e-mail: darja_scorpion@mail.ru
} 


\section{Введение}

В последние десятилетия заметное место в гидрогеологии занимает изучение трансформации подземных вод на урбанизированных территориях под воздействием природных и техногенных факторов [113]. Здесь формируются специфические урбогидросистемы, которые требуют новых подходов для получения достоверных параметров прогностических моделей устойчивого развития городов и обеспечения их эколого-гидрогеологической безопасности.

Город Казань с населением 1.25 миллиона жителей является крупным промышленным и важным культурным центром Российской Федерации с тысячелетней историей. На предприятиях Казани производят авиационную технику, химическую и нефтехимическую продукцию, медицинское и компрессорное оборудование, контрольно-измерительную аппаратуру, изделия легкой и пищевой промышленности. В настоящее время менее $20 \%$ городского водоснабжения осуществляется скважинными водозаборными сооружениями и более $80 \%$ - из поверхностных вод Куйбышевского водохранилища. Для городов Российской Федерации подземные воды являются приоритетным источником водоснабжения как более надежно защищенные от внешнего (техногенного) воздействия [14, 15]. Поэтому обеспечение Казани качественной питьевой водой из защищенных подземных источников наиболее важный геолого-социальный элемент будущего развития города.

\section{Характеристика объекта исследования}

На территории Казани объектами для хозяйственно-питьевого и производственного водоснабжения из подземных источников служат следующие водоносные комплексы (сверху вниз): четвертичный терригенный $(\mathrm{Q}) ;$ неогеновый терригенный $(\mathrm{N})$; пермский сульфатно-карбонатно-терригенный (P). Последний, в свою очередь, делится на казанский карбонатно-терригенный $\left(\mathrm{P}_{2} \mathrm{kz}\right)$ и сакмарский сульфатно-карбонатный $\left(\mathrm{P}_{1} \mathrm{~s}\right)$ гидростратоны. В статье приведена гидрохимическая характеристика подземных вод неогенового комплекса, приуроченных к палеодолине р. Волга.

Бассейн р. Волга сформировался в результате сложного взаимодействия тектонических, геоморфологических и климатических факторов за продолжительный (не менее 10 млн лет) неогенчетвертичный период времени [16]. Поэтому в районе Казани основная часть ресурсов подземных и поверхностных вод приурочена к современной и палеодолине р. Волга. Неогеновые отложения широко распространены и заполняют эрозионную сеть Палео-Волги и ее левых палеопритоков - Казанки и Меши (рис. 1). Поверхность донеогеновых отложений имеет сложный характер и существенно осложнена останцами пермских пород. Ширина палеодолины Волги составляет 9-12 км, а ее тальвег прорезает на отдельных участках кровлю нижнепермских (ассельских и сакмарских) отложений.
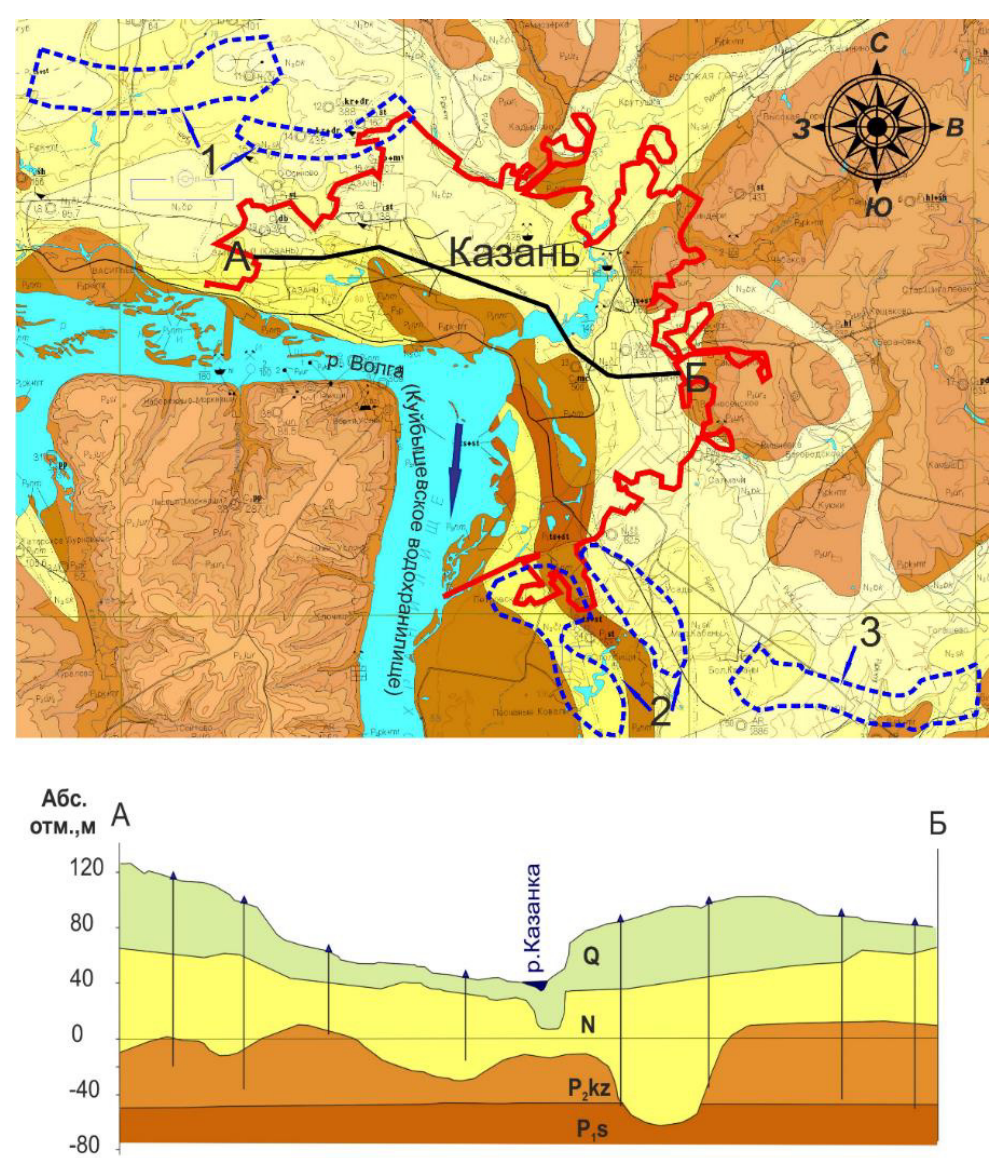

Рис. 1. Геологическая карта (Кочуров, 2002) и геологический разрез г. Казань и прилегающей территории. Цифры на карте - месторождения пресных подземных вод в долине Палео-Волги: 1 - Зеленодольское, 2 - Столбищенское, 3 - Лаишевское. Вертикальные линии на разрезе - водозаборы, вскрывающие неогеновый комплекс.

[Fig. 1. Geological map (Kochurov, 2002) and geological section Kazan and adjacent territory. The numbers on the map are fresh groundwater deposits in the Paleo-Volga valley: 1 - Zelenodolskoye, 2 - Stolbishchenskoye, 3 - Laishevskoye. Vertical lines on the section - water intakes revealing the Neogene complex.] 
Водоносный неогеновый терригенный комплекс объединяет аллювиальные отложения Палео-Волги. Подошва комплекса фиксируется на абсолютных отметках от 35 м до -80 м; водовмещающими породами являются разнозернистые пески с включениями гравия и гальки, с прослоями и линзами глин. Залегая на эрозионной поверхности пермских отложений, неогеновый водоносный комплекс характеризуется весьма изменчивой мощностью: от 10 м над выступами палеозойских пород до 160 м в осевых частях палеоврезов.

В связи со сложной фациальной изменчивостью аллювия и с разной мощностью комплекса, водоносные челнинский, сокольский, чистопольский, биклянский горизонты в его составе не имеют сплошного развития и характеризуются широким диапазоном водообильности. Так, удельные дебиты скважин изменяются от 0.03 до 16.0 л/с, а коэффициенты фильтрации - от 1 до 60 м/сут. Подземные воды представлены гидрокарбонатными кальциевыми пресными водами с преимущественной минерализацией 0.3-0.6 г/л. В пределах наиболее погребенных участков палеодолин минерализация достигает 1.0 г/л. Подземные воды комплекса на территории Казани широко используются групповыми централизованными водозаборами в хозяйственно-питьевых целях, а также для водоснабжения промышленных предприятий.

На рубеже XX и XXI веков методом математического моделирования выполнен подсчет запасов подземных вод Приказанской группы месторождений (Зеленодольское, Столбищенское и Лаишевское), расположенных на левобережье Куйбышевского водохранилица в долине Палео-Волги к северо-западу и юго-востоку от города (рис. 1). Общие запасы подземных вод данной группы месторождений составляют 600 тыс. м³/сут. [17, 18], что может полностью обеспечить потребности г. Казань за счет защищенных подземных вод.

\section{Методика исследований}

Подземные воды неогенового комплекса эксплуатируются в Казани многочисленными (более 120) скважинами и широко используются для водоснабжения. В большинстве скважин проводятся режимные наблюдения за качеством поднимаемых вод. Авторами из геологических отчетов и архивных материалов собраны результаты 378 химических анализов вод неогенового комплекса, выполненных в период с 1971 по 2017 гг. по стандартным методикам в аккредитованных лабораториях Федеральной службы по надзору в сфере защиты прав потребителей и благополучия человека (Роспотребнадзор). Статистическая обработка исходных данных проводилась с помощью программы STATISTICA. При обработке результатов гидрохимических анализов использовались методы базовой и многомерной (кластерный и факторный анализ) статистики. Кластерный анализ выделяет на основе множества переменных компонентов гидрохимического анализа классы (кластеры) параметров, которые более сходны по сравнению с объектами, входящими в другие классы. Наиболее распространенным методом кластерно- го анализа в научных исследованиях является метод древовидной кластеризации с возможностью обнаружения кластеров (ветвей) и их интерпретации. Факторный анализ позволяет выявить зависимость между гидрохимическими данными для исследования статистически связанных признаков с целью выявления определенного числа скрытых (внутренних) причин, формирующих специфику изучаемого явления. С помощью факторного анализа определяется мера связи между параметрами, и выявляются обобщенные факторы, лежащие в основе изменений характеристик. Целью подобного анализа выступает выражение большого числа рассматриваемых параметров через меньшее число более емких внутренних характеристик явления (метод главных компонент). Факторные веса представляют собой количественные значения выделенных факторов для каждого из имеющихся объектов.

Для построения карт-моделей пространственной изменчивости компонентов применялся программный пакет «ArcGisMap», который предоставляет широкий выбор различных методов интерполяции. Для химических показателей водоносного неогенового комплекса интерполяция значений проводилась с помощью метода ординарного кригинга [19].

\section{Результаты исследования и обсуждение}

Для выявления трендов изменения состава подземных вод нами впервые проведен ретроспективный анализ гидрохимических проб неогенового комплекса г. Казань за почти полувековой период (19712017 гг.) после создания крупнейшего в Евразии Куйбышевского водохранилища [20]. Для сравнительного анализа тенденций в поведении компонентов с помощью гидрохимических моделей данные по городским скважинам, эксплуатирующим воды неогенового комплекса, разделены на 2 периода: первый включает результаты 1971-1999 гг., второй - 2000-2017 гг. Сравнение значений химических компонентов по периодам показал следующее (табл. 1, рис. 2).

В водоносном неогеновом комплексе практически все основные компоненты (водородный показатель, минерализация, все катионы и анионы, нитраты, аммиак, окисляемость) не превышают значений предельно допустимых концентраций (ПДК) для питьевых вод [21]. Это подтверждает питьевое качество вод неогенового комплекса по сравнению с ниже залегающими комплексами: казанским и сакмарским (табл. 1).

Для минерализации вод неогенового комплекса характерны колебания значений от 100 до 838 мг/л при средних значениях 559 и 600 мг/л (ПДК для минерализации 1000 мг/л), соответственно, для первого (1971-1999 гг.) и второго (2000-2017 гг.) периодов (табл. 1). Намечается тенденция незначительного повышения в XXI веке минерализации в центральной (исторической) и южной (промышленной) частях города (рис. 2). Возможно, это связано с пониженной защищенностью вод неогенового комплекса сверху в долине р. Казанка [22] и старым фондом скважин промышленных предприятий. 

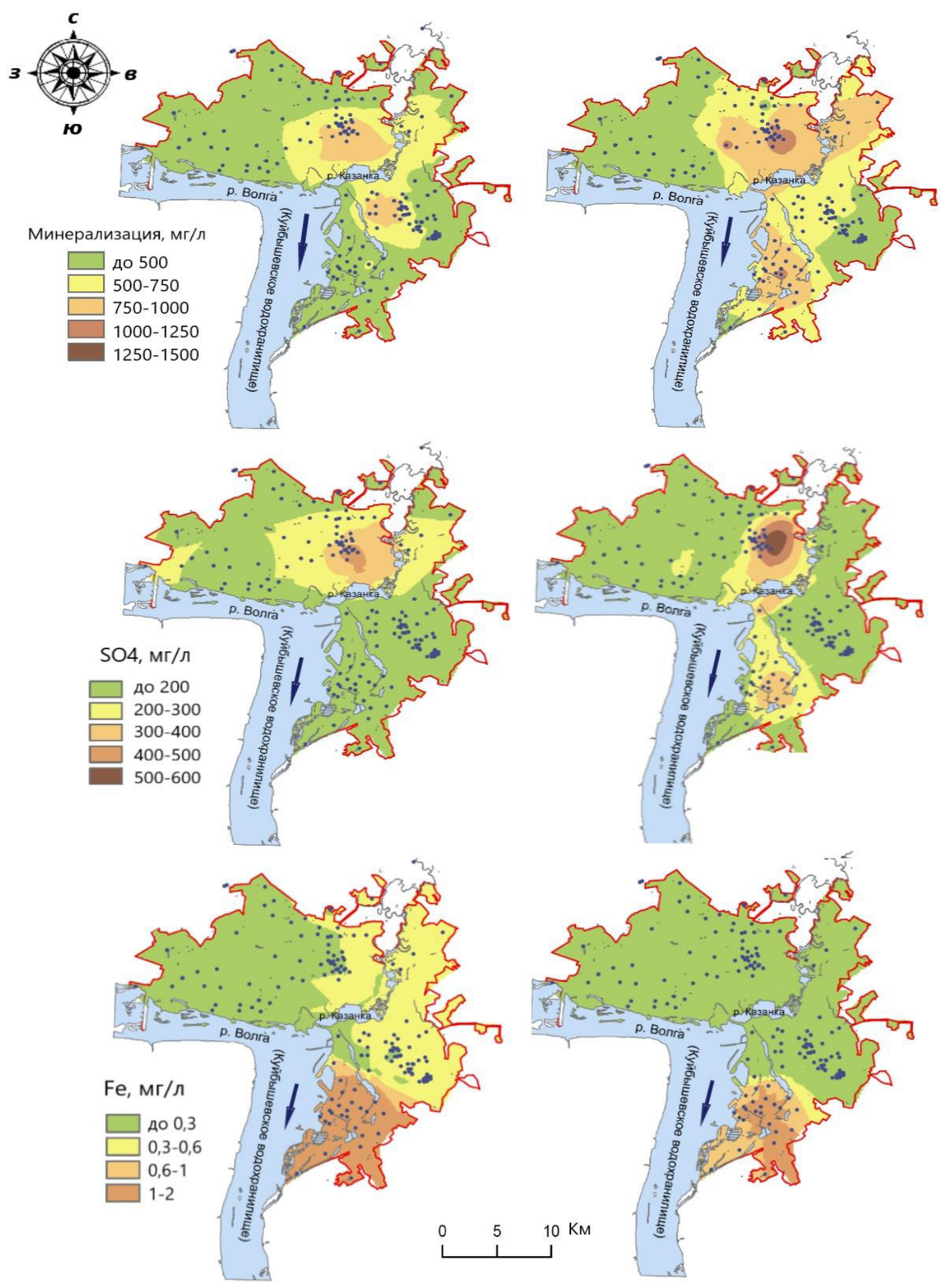

Рис. 2. Гидрохимические модели основных компонентов подземных вод неогенового комплекса г. Казань. Слева - период 1971-1999 гг. Справа - период 2000-2017 гг. Точки - скважины, эксплуатирующие неогеновый комплекс.

[Fig. 2. Hydrochemical models of the main components of groundwater in the Neogene complex of Kazan. Left - the period 1971-1999 years. Right - the period 2000-2017 years. Points - wells operating the Neogene complex.]

Для сульфатов характерны примерно такие же тенденции, как и для минерализации: колебания от первых десятков до 560 мг/л (при ПДК 500 мг/л) при средних значениях 134 и 145 мг/л, соответственно, для первого и второго периодов (табл. 1). Наиболее высокие содержания сульфатов встреча- ются в скважинах на правобережье р. Казанка при исследованиях в XXI веке. Хлориды, в целом, нехарактерны для вод неогенового комплекса и их содержания в среднем составляют 15-24 мг/л (ПДК 350 мг/л). В единичных пробах содержание хлоридов может приближаться к ПДК (до 347 мг/л). 
Табл. 1. Средние содержания основных компонентов в подземных водах г. Казань

[Tabl. 1. Average contents of the main components in the underground waters of Kazan]

\begin{tabular}{|c|c|c|c|c|c|c|}
\hline \multirow{3}{*}{$\begin{array}{c}\text { Компонент, } \\
\text { единица измерения } \\
\text { [Component, } \\
\text { unit of measure] }\end{array}$} & \multicolumn{6}{|c|}{$\begin{array}{c}\text { Водоносные комплексы, периоды наблюдений } \\
\text { [Aquifers, observation periods] }\end{array}$} \\
\hline & \multicolumn{2}{|c|}{ Сакмарский } & \multicolumn{2}{|c|}{ Казанский } & \multicolumn{2}{|c|}{ Неогеновый } \\
\hline & 1960-1999 & $2000-2020$ & 1960-1999 & $2000-2020$ & 1971-1999 & 2000-2017 \\
\hline Жесткость, ${ }^{\mathrm{O}}$ [Rigidity] & 15.90 & 11.20 & 17.15 & 17.33 & 7.58 & 8.41 \\
\hline pH, ед. $\mathrm{pH}$ & 7.58 & 7.40 & 7.16 & 7.20 & 7.03 & 7.27 \\
\hline $\begin{array}{l}\text { Окисляемость } \\
\text { перманганатная, } \mathrm{M \Gamma O}_{2} / \text { л } \\
\text { [Permanganate oxidizability] }\end{array}$ & 1.84 & 1.35 & 1.24 & 1.21 & 3.38 & 1.44 \\
\hline $\begin{array}{l}\text { Минерализация, мг/л } \\
\text { [Mineralization] }\end{array}$ & 1009.3 & 787.4 & 1282.7 & 1386.5 & 558.9 & 599.5 \\
\hline $\mathrm{Ca}^{2+}, \mathrm{мг} / л$ & 144.30 & 142.60 & 228.90 & 274.90 & 144.3 & 94.02 \\
\hline $\mathrm{Mg}^{2+}$, мг/л & 53.50 & 40.74 & 71.10 & 46.50 & 33.00 & 23.08 \\
\hline $\mathrm{Na}^{+}+\mathrm{K}^{+}, \mathrm{мг/л}$ & 14.10 & 22.50 & 23.80 & 51.60 & 26.17 & 16.48 \\
\hline $\mathrm{HCO}_{3}^{-}, \mathrm{мг} / л$ & 344.80 & 364.60 & 385.50 & 333.00 & 348.69 & 312.41 \\
\hline $\mathrm{SO}_{4}^{-}$, мг/л & 522.85 & 232.40 & 571.20 & 301.60 & 134.28 & 145.14 \\
\hline $\mathrm{Cl}^{-}, \mathrm{мг} / л$ & 7.4 & 7.30 & 16.40 & 33.20 & 14.84 & 24.15 \\
\hline $\mathrm{Fe}$ общ., мг/л & 0.35 & 0.38 & 0.19 & 0.26 & 0.68 & 0.29 \\
\hline $\mathrm{NO}_{3}^{-}$, мг/л & 0.90 & 6.80 & 1.90 & 10.50 & 3.07 & 8.42 \\
\hline $\mathrm{NH}_{4}^{-}, \mathrm{мг/л}$ & 0.13 & 0.09 & 0.09 & 0.11 & 0.18 & 0.11 \\
\hline $\begin{array}{l}\text { Количество анализов } \\
\text { [Number of analyzes] }\end{array}$ & 72 & 549 & 970 & 249 & 196 & 182 \\
\hline
\end{tabular}

Другая тенденция выявляется для общего железа в водах неогенового комплекса. Содержания железа превышают ПДК0.3 мг/л в более половине скважин, что характерно для приповерхностных кайнозойских водоносных горизонтов Камско-Вятского артезианского бассейна. Из анализа гидрохимических моделей (рис. 2) следует, что превышения относительно ПДК железа в XX веке фиксировались в восточной и южной частях г. Казань. В XXI веке намечается сокращение площади «зараженных» железом подземных вод в неогеновом комплексе. Превышение ПДК отме-
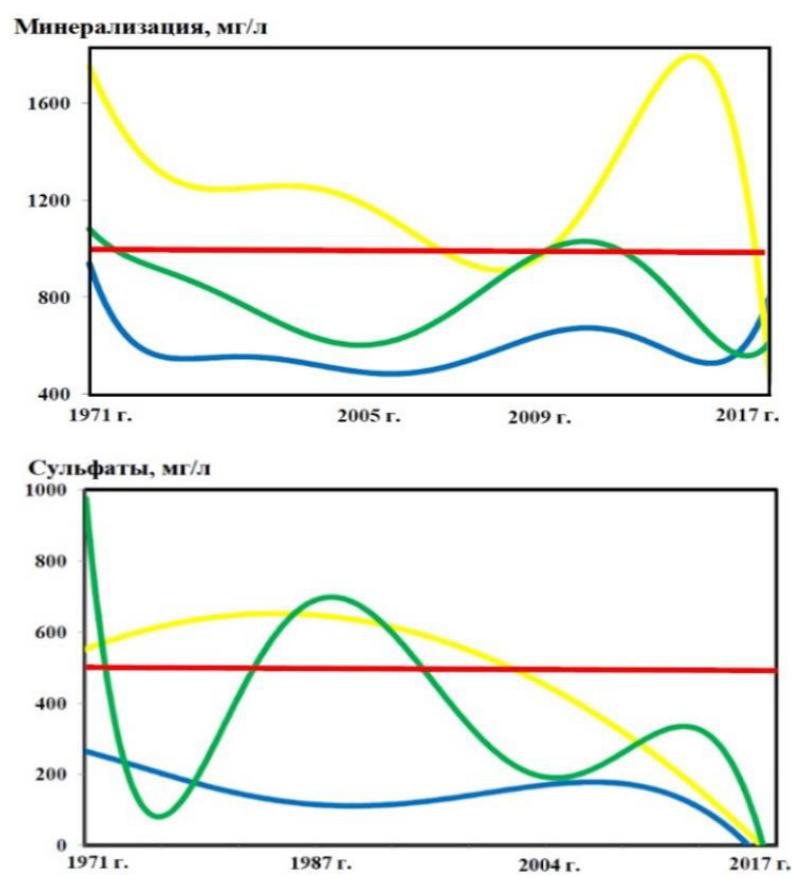

чаются только в южной (промышленной) зоне, что возможно связано с непостоянной эксплуатацией водозаборных скважин промышленных предприятий в последние годы в связи с сокращением производственных мощностей и природной реабилитацией подземных вод.

Тренд распределения компонентов за период с 1971 по 2017 гг. в основных водоносных комплексах показал (рис. 3), что неогеновый комплекс по качеству вод (содержания основных лимитируемых показателей

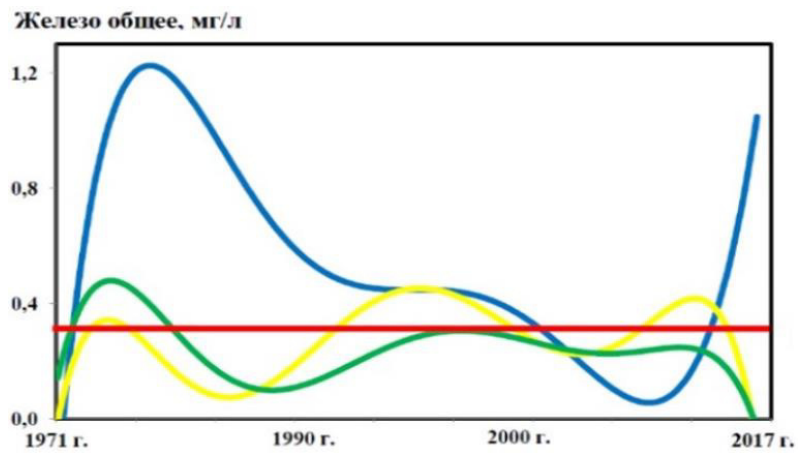

Рис. 3. Тренды изменения содержаний основных компонентов в подземных водах г. Казань за период 1971-2017 гг. Гидростратоны: синий цвет -неогеновый, желтый цвет - казанский,зеленый - сакмарский. Красная линия - ПДК компонента по [20]

[Fig. 3. Trends in the content of the main components in groundwater in Kazan for the period 1971-2017 years. Aquifers: blue - Neogene, yellow - Kazanian, green - Sakmarian. Red line - MPC of the component. according to [20].] 
минерализации и сульфатов) значительно превосходит пермские комплексы. Поэтому подземные воды палеодолины Волги за пределами городской черты могут рассматриваться самым перспективным объектом водоснабжения Казани из защищенных подземных источников. В целом, этот вывод подтверждается и низкими (на 1-2 порядка ниже ПДК) содержаниями микрокомпонентов, включая тяжелые металлы [23]. Все это свидетельствует об отсутствии (или незначительном) влиянии антропогенного и техногенного загрязнений на водоносные неогеновые горизонты.

Обработка результатов анализов вод неогенового комплекса г. Казань с помощью кластерного и факторного анализов выявила «природные» и «техногенные» компоненты (рис. 4. табл. 2). К техногенным компонентам можно отнести хлориды и общее железо, а также натрий и калий. Компонентами вод неогенового комплекса, которые отвечают за природные особенности, являются гидрокарбонаты, магний, кальций, минерализация, общая жесткость. При сравнении кластерных диаграмм по периодам наблюдений выявляются некоторые различия (рис. 4), которые, по нашему мнению, могут быть связаны c разной степенью техногенной нагрузки на воды

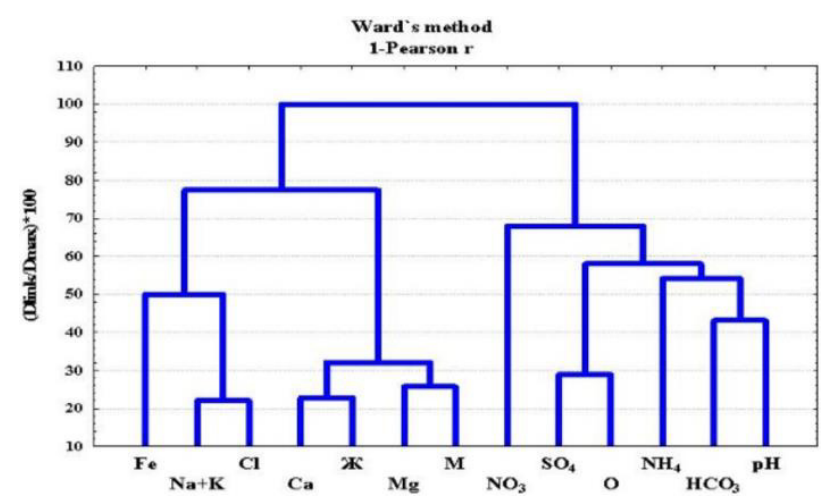

неогенового комплекса Казани в XX и XXI веках. Так, кластерная диаграмма начала XXI века характеризуется достаточно тесной связью между компонентами (ближе к нулевой линии), а для конца прошлого века связи между компонентами менее явные (дальше от нулевой линии). По нашему мнению, это может быть свидетельством более сильного влияния техногенного фактора (более интенсивная эксплуатация водозаборных скважин на промышленных предприятиях) на гидрохимический состав вод неогенового комплекса в конце XX века и, особенно, в период 1971-1990 гг. когда городская промышленность интенсивно развивалась. Подобный же вывод следует из анализа веса факторных нагрузок (табл. 2). Из данных таблицы видно, что природная составляющая неогенового комплекса в начале XXI века выше (35.5\%). чем в XX веке $(23.5 \%)$. Однако и рассмотрение «техногенных» факторов для 2-х периодов наблюдений показывает, что техногенная нагрузка на подземные воды неогенового комплекса в начале XXI века выше (22\%), чем в XX веке (16\%). Возможно, это связано с большим сроком (40-50 лет) эксплуатации скважин для централизованного водоснабжения.

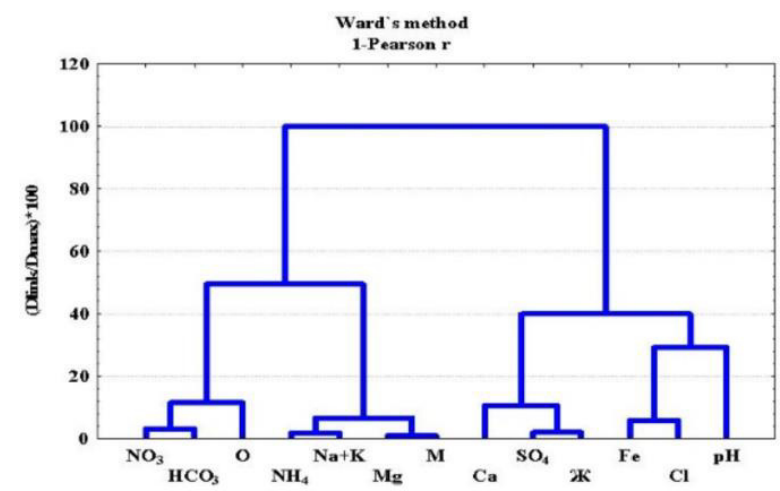

Рис. 4. Кластерные диаграммы основных компонентов в водах неогенового комплекса. Слева - период 1971-1999 гг., справа период 2000-2017 гг, $M$ - минерализация, $Ж$ - общая жесткость, $O$ - окисляемость.

[Fig. 4. Cluster diagrams of major components in the waters of the Neogene complex. Left - the period 1971-1999 years, right - the period 2000-2017 years, $M$ - mineralization, $W$ - rigidity, $O$ - oxidizability.]

Табл. 2. Факторные нагрузки для компонентов неогенового комплекса [Tabl. 2. Factor loads for the components of the Neogene complex]

\begin{tabular}{|c|c|c|c|c|}
\hline \multirow{2}{*}{$\begin{array}{l}\text { Компонент } \\
\text { [Component] }\end{array}$} & \multicolumn{2}{|c|}{$\begin{array}{c}\text { «Природный» фактор } \\
\text { ["Natural" factor] }\end{array}$} & \multicolumn{2}{|c|}{$\begin{array}{l}\text { «Техногенный» фактор } \\
\text { ["Technogenic" factor] }\end{array}$} \\
\hline & 1971-1999 & $2000-2017$ & 1971-1999 & $2000-2017$ \\
\hline 1 & 2 & 3 & 4 & 5 \\
\hline $\begin{array}{c}\text { Водородный показатель }(\mathrm{pH}) \\
\text { [hydrogen parameter }(\mathrm{pH})]\end{array}$ & 0.13 & -0.28 & -0.29 & -0.08 \\
\hline $\begin{array}{l}\text { Минерализация } \\
\text { [Mineralization] }\end{array}$ & 0.70 & 0.96 & 0.24 & 0.07 \\
\hline $\begin{array}{c}\text { Жесткость общая } \\
\text { [rigidity] }\end{array}$ & 0.75 & 0.05 & 0.03 & 0.23 \\
\hline $\begin{array}{c}\text { Окисляемость перманганатная } \\
\text { [Permanganate oxidizability] }\end{array}$ & -0.13 & 0.44 & 0.19 & -0.50 \\
\hline $\begin{array}{c}\text { Гидрокарбонаты }\left(\mathrm{HCO}_{3}\right) \\
{\left[\text { Hydrocarbonates }\left(\mathrm{HCO}_{3}\right)\right]}\end{array}$ & 0.25 & 0.11 & 0.19 & -0.71 \\
\hline $\begin{array}{c}\text { Хлориды }(\mathrm{Cl}) \\
{[\text { Chlorides }(\mathrm{Cl})]}\end{array}$ & 0.45 & -0.29 & 0.63 & 0.88 \\
\hline
\end{tabular}


Продолжение Табл. 1

[Continued Table 1]

\begin{tabular}{|c|c|c|c|c|}
\hline 1 & 2 & 3 & 4 & 5 \\
\hline $\begin{array}{l}\text { Сульфаты }\left(\mathrm{SO}_{4}\right) \\
{\left[\text { Sulphates }\left(\mathrm{SO}_{4}\right)\right]} \\
\end{array}$ & 0.36 & 0.27 & 0.33 & 0.32 \\
\hline $\begin{array}{c}\text { Нитраты }\left(\mathrm{NO}_{3}\right) \\
{\left[\text { Nitrates }\left(\mathrm{NO}_{3}\right)\right]} \\
\end{array}$ & 0.06 & -0.12 & -0.53 & -0.93 \\
\hline $\begin{array}{l}\text { Натрий, калий, суммарно }(\mathrm{Na}+\mathrm{K}) \\
{[\text { Sodium, potassium, total }(\mathrm{Na}+\mathrm{K})]}\end{array}$ & 0.13 & 0.86 & 0.84 & -0.13 \\
\hline $\begin{array}{c}\text { Кальций }(\mathrm{Ca}) \\
{[\text { Calcium }(\mathrm{Ca})]} \\
\end{array}$ & 0.81 & -0.38 & -0.17 & 0.14 \\
\hline $\begin{array}{c}\text { Магний }(\mathrm{Mg}) \\
{[\text { Magnesium }(\mathrm{Mg})]}\end{array}$ & 0.79 & 0.98 & 0.15 & 0.05 \\
\hline $\begin{array}{c}\text { Аммоний }\left(\mathrm{NH}_{4}\right) \\
{\left[\text { Ammonium }\left(\mathrm{NH}_{4}\right)\right]}\end{array}$ & -0.52 & 0.93 & 0.07 & -0.05 \\
\hline $\begin{array}{l}\text { Железо общее }(\mathrm{Fe}) \\
\text { [Iron total }(\mathrm{Fe})]\end{array}$ & 0.01 & -0.73 & 0.55 & 0.50 \\
\hline $\begin{array}{c}\text { Вес фактора, \% } \\
\text { [Factor weight] }\end{array}$ & 23.50 & 35.48 & 15.84 & 21.88 \\
\hline
\end{tabular}

Примечание: красным цветом выделены значимые нагрузки отдельных компонентов в факторах

\section{Заключение}

На основе выполненного исследования можно сделать следующие выводы.

1. Впервые проведен анализ площадного распределения основных компонентов в подземных водах неогенового комплекса г. Казань за большой (19712017 гг.) период наблюдений.

2. На основе мониторинговых исследований, статистических методов с применением ГИС-технологий показаны количественные изменения содержаний основных гидрохимических компонентов на промышленно-урбанизированной территории.

3. Высокое качество подземных вод палеодолины Волги позволяет считать их самым высокоперспективным объектом водоснабжения Казани из защищенных подземных источников.

Конфликт интересов: Авторы декларируют отсутствие явных и потенциальных конфликтов интересов, связанных с публикацией настоящей статьи.

\section{ЛИТЕРАТУРА}

1. Белоусова А. П., Гавич И. К., Лисенков А. Б., Попов Е. В. Экологическая гидрогеология. М.: ИКЦ «Академкнига». 2006. $397 \mathrm{c}$.

2. Бочаров В. Л., Строгонова Л. Н., Овчинникова Е. С. Проблемы изучения и использования ресурсов подземных питьевых вод Воронежской области // Вестник Воронежского государственного университета. Серия: Геология. 2010. № 1. C. $243-251$.

3. Злобина В. Л., Медовар Ю. А., Юшманов И. О. Трансформация состава и свойств подземных вод при изменениях окружающей среды. М.: Мир науки. 2017. 191 с.

4. Косинова И. И., Сигора Г. А., Ничкова Л. А., Добровольская Е. В., Симонова Е. С. Мониторинг загрязненности нитрат-ионами подземных вод территории городов Севастополь и Бахчисарай // Вестник Воронежского государственного университета. Серия: Геология. 2016. № 3. C. $123-127$.

5. Крайнов С. Р., Рыженко Б. Н., Швец В. М. Геохимия подземных вод. Теоретические, прикладные и экологические аспекты. М.: Наука. 2004. 677 с.
6. Техногенные процессы в подземных водах. Под ред. проф. И.К. Гавич. М.: Научный мир. 2003. 248 с.

7. Мусин Р. Х., Курлянов Н. А., Файзрахманова 3. Г., Мусина Р. 3. О качестве вод, используемых в системах питьевого водоснабжения города Казани // Георесурсы. 2014. № 3. C. 9-16.

8. Сунгатуллин Р. Х. Химический состав подземной и поверхностной гидросфер (на примере НабережноЧелнинской площади) // Ученые записки КГУ. Естественные науки. 2009. Т. 151. № 3. С. 153-166.

9. Сунгатуллин Р. Х. Влияние техногенеза на формирование современных кор выветривания и водоносных ареалов // Геоэкология. Инженерная геология. Гидрогеология. Геокриология. 2010. № 6. С. 494-502.

10. Сунгатуллин Р. Х., Хазиев М. И. Системный подход при изучении гидросферы на промышленно-урбанизированных территориях // Геоэкология. Инженерная геология. Гидрогеология. Геокриология. 2009. № 1. С. 19-31.

11. Шварц А. А. Химический состав подземных вод СанктПетербургского региона в свете новых требований к качеству питьевой воды // Вестник СПбГУ. Сер. 7. 2005. вып. 1. C. $85-93$.

12. Щукова И. В. Формирование химического состава подземных вод зоны активного водообмена на территории г. Перми: автореф. дис... канд. геол.-минерал. наук. Пермь. 2005. 23 c.

13. Barrett M.H., Hiscock K.M., Pedley S., Lerner D.N., Tellam J.H., French M. J. Marker species for identifying urban groundwater recharge sources. A review and case study in Nottingham. UK. // Water Res. 1999. V. 33. № 14. P. 3083-3097. DOI: https://doi.org/10.1016/S0043-1354(99)00021-4

14. Зекцер И. С. Подземные воды как компонент окружающей среды. М.: Научный мир. 2001. 328 с.

15. Зекцер И. С., Каримова О. А., Четверикова А. В. Современное состояние и перспективы использования пресных подземных вод для водоснабжения городов // Изв. вузов. Геология и разведка. 2016. № 1. С. 75-76.

16. Горецкий Г. И. Формирование долины р. Волги в раннем и среднем антропогене. Аллювий Пра-Волги. М.; Наука. 1966. 412 с.

17. Гараева Т. В., Жоров А. А., Олиферова О. А. Оценка возможного влияния эксплуатации Зеленодольского месторождения подземных вод на экосистемы Волжско-Камского 
заповедника: противоречия и компромиссы // Геоэкология. Инженерная геология. Гидрогеология. Геокриология. 2015. № 5. С. 387-399.

18. Олиферова О. А., Гараева Т. В. Оценка возможного влияния эксплуатации проектного Зеленодольского водозабора на природную среду Волжско-Камского заповедника // Разведка и охрана недр. 2010. № 10. С. 37-42.

19. Rezaee H., Asghari O., Yamamoto J. K. On the reduction of the ordinary kriging smoothing effect // Journal of Mining and Environment. 2011. V. 2. P. 102-117.

20. Петрова Д. И. Трансформация подземных вод г. Казань в связи с созданием Куйбышевского водохранилища // Геология в развивающемся мире. Сб. научных трудов по мате- риалам XIII Международной научно-практической конференции студентов, аспирантов и молодых ученых. Пермь. 2020. C. $510-512$.

21. СанПиН 2.1.4.1074-01. Питьевая вода. Гигиенические требования к качеству воды централизованных систем питьевого водоснабжения. Контроль качества. М.. 2001. 62 с. 22. Геология Приказанского района / под ред. А. И. Шевелева. Казань: Изд-во ЗАО «Новое знание». 2007. 208 с

23. Петрова Д. И. Тяжелые металлы в подземных водах неогенового комплекса г. Казань // Молодежная научная конференция памяти К. О. Кратца. СПб.: Изд-во ВВМ. 2020. C. 222-224.

UDC 556.314

ISSN 1609-0691

DOI: https://doi.org/10.17308/geology.2021.1/3343

Received: 10.12 .2020

Accepted: 01.03.2021

Published online: 31.03.2021

\title{
Hydrogeochemical characteristics of underground waters of Neogene sediments Paleo-Volga within the territory of Kazan
}

\author{
CC2021 D. I. Petrova ${ }^{\varpi}$, R. Kh. Sungatullin \\ Kazan Federal University, 18 Kremlyovskaya st., Kazan, 420008, Russian Federation
}

\begin{abstract}
Introduction: One of the sources of drinking water and industrial water supply in Kazan is the waterbearing Neogene terrigenous system. The aim of the study is to give hydrogeochemical characteristics to ground water of the Neogene system in terms of providing the city of Kazan with high-quality drinking water from protected underground sources.

Methodology: The study used hydrochemical data from geological records and archives for the period from 1971 to 2017. The methods of mathematical statistics (basic, cluster, and factor analysis) allowed to differentiate natural and man-made components. GIS-modelling using the ArcGisMap package showed the spatial variability of the main components in the waters of the Neogene system at the turn of the 20th and 21 st centuries.

Results and discussion: 2 groups of components were distinguished in the studied water-bearing system: "natural" and "man-made". The natural components include hydrocarbonates, magnesium, calcium, mineralisation, and total hardness. Man-made components are chlorides, total iron, sodium, and potassium. In the 21st century, there has been an increase in the anthropogenic impact on underground water wells of centralized water supply from the Neogene system, due to their long (40-50 years) service life.

Conclusions: Hydrochemical characteristics of the water-bearing Neogene terrigenous system are estimated as being favourable, since nearly all key components do not exceed the limit values for the maximum permissible concentration (MPC) for drinking water. The high quality groundwater of the Volga paleovalleys allows us to consider them as being the most promising groundwater supply source in Kazan.
\end{abstract}

\footnotetext{
${ }^{\square}$ Daria I. Ivanova, e-mail: darja_scorpion@mail.ru
} 
Keywords: groundwater, paleovalley, Neogene system, hydrochemistry, statistics, GIS, technogenesis, monitoring, Volga, Kazan.

Funding: The work has been financed by subsidies obtained within the state support of Kazan Federal University aimed at improving its competitiveness among the world's leading research and education centres.

For citation: Petrova D. I., Sungatullin R. Kh. Hydrogeochemical characteristics of underground waters of PaleoVolga Neogene sediments within the territory of Kazan. Vestnik Voronezhskogo gosudarstvennogo universiteta. Seriya: Geologiya - Proceedings of Voronezh State University. Series: Geology. 2021, no.1, pp. 114-123. DOI: https://doi.org/10.17308/geology.2021.1/3343

\section{REFERENCES}

1. Belousova A. P, Gavich I. K., Lisenkov A. B., Popov E. V. Ekologicheskaya gidrogeologiya [Ecological hydrogeology] Moscow, Akademkniga publ., 2006, 397 p. (In Russ.)

2. Bocharov V. L., Strogonova L. N., Ovchinnikova E. S. Problems of study and use of underground drinking water resources of the Voronezh region. Vestnik Voronezhskogo gosudarstvennogo universiteta. Seriya: Geologiya - Proceedings of Voronezh State University. Series: Geology, 2010, no. 1, pp. 243-251. (In Russ.)

3. Zlobina V. L., Medovar Yu. A., Yushmanov I. O. Transformatsiya sostava $i$ svoistv podzemnykh vod pri izmeneniyakh okruzhayushchei sredy [Transformation of the composition and properties of groundwater under environmental changes]. Moscow, Mir nauki publ., 2017, 191 p. (In Russ.)

4. Kosinova I. I., Sigora G. A., Nichkova L. A., Dobrovolskaya E. V., Simonova E. S. Monitoring of contamination by nitrate ions of groundwater in the cities of Sevastopol and Bakhchisarai. Vestnik Voronezhskogo gosudarstvennogo universiteta. Seriya: Geologiya = Proceedings of Voronezh State University. Series: Geology,2016, no. 3, pp. 123-127. (In Russ.)

5. Krainov S. R., Ryzhenko B. N., Shvets V. M. Geokhimiya podzemnykh vod. Teoreticheskie, prikladnye i ekologicheskie aspekty [Geochemistry of underground waters. Theoretical, applied and environmental aspects]. Moscow, Nauka publ., 2004, 677 s. (In Russ.)

6. Tekhnogennye protsessy v podzemnykh vodakh [Technogenic processes in groundwater]. Ed. prof. I.K. Gavich. Moscow, Nauchnyi mir publ., 2003, 248 p. (In Russ.)

7. Musin R. Kh., Kurlyanov N. A., Fayzrakhmanova Z. G., Musina R. Z. O kachestve vody, ispol'zuemoi v sistemakh pit'evogo vodosnabzheniya g. Kazani [About the quality of waters used in drinking water supply systems in Kazan].Georesursy, 2014, no. 3, pp. 9-16. (In Russ.)

8. Sungatullin R. Kh. Khimicheskii sostav podzemnykh i poverkhnostnykh gidrosfer (na primere Naberezhno-Chelninskoi oblasti). [Chemical composition of underground and surface hydrospheres (on the example of Naberezhno-Chelninskaya area)]. Uchenye Zapiski Kazanskogo Universiteta. Seriya Estestvennye Nauki= Proceedings of Kazan University. Natural Sciences Series, 2009, vol. 151, no. 3, pp. 153-166. (In Russ.)

9. Sungatullin R. Kh. Vliyanie tekhnogeneza na formirovanie sovremennykh kor vyvetrivaniya i vodonosnykh territorii [Influence of technogenesis on the formation of modern weathering crusts and water-bearing areas]. Geoecology. Engineering geology. Hydrogeology. Geocryology - Geoekologiya. Inzhenernaya geologiya. Gidrogeologiya. Geokriologiya, 2010, no. 6, pp. 494-
502. (In Russ.)

10. Sungatullin R. Kh., Khaziev M. I. Sistemnyi podkhod k izucheniyu gidrosfery industrial'no-urbanizirovannykh territorii [A systematic approach to the study of the hydrosphere in industrial-urbanized territories]. Geoecology. Engineering geology. Hydrogeology. Geocryology - Geoekologiya. Inzhenernaya geologiya. Gidrogeologiya. Geokriologiya, 2009, no. 1, pp. 1931. (In Russ.)

11. Schwartz A. A. Khimicheskii sostav podzemnykh vod v raione Sankt-Peterburga $\mathrm{s}$ uchetom novykh trebovanii $\mathrm{k}$ kachestvu pit'evoi vody [Chemical composition of groundwater in the St. Petersburg region in the light of new requirements for the quality of drinking water]. Vestnik Sankt-Peterburgskogo universiteta. Nauki o Zemle - Vestnik of Saint-Petersburg University. Earth Sciences, 2005, no. 1, pp. 85-93. (In Russ.)

12. Shchukova I. V.Formirovanie khimicheskogo sostava podzemnykh vod zony aktivnogo vodoobmena na territorii g. Permi: avtoref. dis... kand. geol.-mineral. nauk. [Formation of the chemical composition of groundwater in the zone of active water exchange on the territory of Perm: author. dis ... cand. geol.mineral. Sciences]. Perm, 2005, 23 p. (In Russ.)

13. Barrett M. H., Hiscock K.M., Pedley S., Lerner D.N., Tellam J.H., French M. J. Marker species for identifying urban groundwater recharge sources. A review and case study in Nottingham. UK. Water Res. 1999, vol. 33, no. 14, pp. 3083-3097. DOI: https://doi.org/10.1016/S0043-1354(99)00021-4

14. Zektser I. S. Podzemnye vody kak komponent okruzhayushchei sredy [Underground waters as a component of the environment]. Moscow, Nauchnyi mir publ., 2001, 328 p. (In Russ.)

15. Zektser I. S., Karimova O. A., Chetverikova A. V. Sovremennoe sostoyanie i perspektivy ispol'zovaniya presnykh podzemnykh vod dlya vodosnabzheniya gorodov [Current state and prospects of fresh groundwater use for water supply of cities]. Izv. vuzov. Geologiya i razvedka $=$ Izv. universities. Geology and exploration, 2016, no. 1, pp. 75-76. (In Russ.)

16. Goretsky G. I. Formirovanie doliny r. Volgi v rannem $i$ srednem antropogene. Allyuvii Pra-Volgi. [Formation of the river valley. Volga in the early and middle anthropogen. Alluviy Pra-Volga]. Moscow, Nauka publ., 1966, 412 p. (In Russ.)

17. Garayeva T. V., Zhorov A. A., Oliferova O. A. Otsenka vozmozhnogo vozdeistviya ekspluatatsii Zelenodol'skogo mestorozhdeniya podzemnykh vod na ekosistemy VolzhskoKamskogo zapovednika: protivorechiya i kompromissy [Assessment of the possible impact of exploitation of the Zelenodolsk groundwater deposit on the ecosystems of the VolzhskoKamsky reserve: contradictions and compromises]. Geoecology. Engineering geology. Hydrogeology. Geocryology - Geoekologiya. Inzhenernaya geologiya. Gidrogeologiya. Geokriologiya, 2015, no. 5, pp. 387-399. (In Russ.)

18. Oliferova O. A., Garayeva T. V. Otsenka vozmozhnogo vozdeistviya ekspluatatsii proektnogo Zelenodol'skogo vodozabora na prirodnuyu sredu Volgo-Kamskogo zapovednika. [Assessment of the possible impact of the exploitation of the design Zelenodolsk water intake on the natural environment of the Volga-Kama nature reserve]. Razvedka i okhrana nedr $=$ Exploration and conservation of mineral resources. 2010, no. 10, pp. 37-42. (In Russ.)

19. Rezaee H., Asghari O., Yamamoto J. K. On the reduction of the ordinary kriging smoothing effect. Journal of Mining and Environment. 2011. V. 2. 102-117 p.

20. Petrova D. I. Transformatsiya podzemnykh vod g. Kazan' v svyazi s sozdaniem Kuibyshevskogo vodokhranilishcha [Groundwater transformation of Kazan in connection with the creation of the Kuibyshev reservoir] // Geologiya v razvivayushchemsya mire [Geology in the developing world]. Sat. scientific papers based on the materials of the XIII International scientific- 
practical conference of students, graduate students and young scientists. Permian. 2020, pp. 510-512. (In Russ.)

21. SanPiN 2.1.4.1074-01. Pit'evaya voda. Gigienicheskie trebovaniya $k$ kachestvu vody tsentralizovannykh sistem pit'evogo vodosnabzheniya. Kontrol' kachestva [SanPiN 2.1.4.1074-01. Drinking water. Hygienic requirements for water quality of centralized drinking water supply systems. Quality control]. Moscow, 2001, 62 p. (In Russ.)
22. Geologiya Prikazanskogo raiona [Geology of the Prikazan region]. ed. A. I. Sheveleva. Kazan, Publishing house of CJSC Novoe znanie, 2007, 208 p. (In Russ.)

23. Petrova D. I. Tyazhelye metally v podzemnykh vodakh neogenovogo kompleksa g. Kazan' [Heavy metals in underground waters of the Neogene complex of Kazan]. Molodezhnaya nauchnaya konferentsiya pamyati K. O. Krattsa. [Youth scientific conference in memory of KO Kratts]. St. Petersburg, Publishing house of VVM, 2020, pp. 222-224. (In Russ.)
Петрова Дарья Ивановна - аспирант, Казанский Федеральный Университет, Казань, Российская Федерация;

E-mail: darja_scorpion@mail.ru;

ORCID http://orcid.org/0000-0002-9432-6815

Сунгатуллин Рафаэль Харисович - д. г.-м. н., профессор, Казанский Федеральный Университет, Казань, Российская Федерация; E-mail: Rafael.Sungatullin@kpfu.ru; ORCID http://orcid.org/ 0000-0001-7275-1549

Авторы прочитали и одобрили окончательный вариант рукописи.
Daria I. Ivanova - postgraduate student, Kazan Federal University, Kazan, Russian Federation;

E-mail: darja_scorpion@mail.ru;

ORCID http://orcid.org/0000-0002-9432-6815

Rafael Kh. Sungatullin - PhD, Dr. habil. in Geol.-Min., Professor, Kazan, Russian Federation;

E-mail: Rafael.Sungatullin@kpfu.ru;

ORCID http://orcid.org/ 0000-0001-7275-1549

The authors have read and approved the final manuscript. 